\title{
Hydrodynamic Effects of Debris Blockage and Scour on Masonry Bridges: Towards Experimental Modelling
}

\author{
M. Ebrahimi, P. Kripakaran, S. Djordjević, G. Tabor \& R. Kahraman \\ Centre for Water Systems, University of Exeter, Exeter, Devon, United Kingdom \\ D.M. Prodanović \\ Faculty of Civil Engineering, University of Belgrade, Belgrade, Serbia \\ S. Arthur \\ School of the Built Environment, Heriot-Watt University, Edinburgh, Lothian, United Kingdom
}

\begin{abstract}
This paper describes the preliminary stage of an ongoing project investigating the hydrodynamic effects of debris blockage at masonry bridges. Debris blockage is cited as one of the primary causes of bridge failures in the UK and around the world. Masonry bridges, many of which are valuable historical assets, are particularly vulnerable to debris blockage due to their short spans and low clearance. This paper presents work done as part of the first phase of the project involving experimental research to understand the scientific relationships between debris characteristics and flow conditions. The study, being carried out at Centre for Water Systems at University of Exeter, utilizes a $0.6 \mathrm{~m}$-wide and $10 \mathrm{~m}$-long flume to run hydraulic experiments in order to characterize the impact of debris blockage on flow hydrodynamics, scour, and hydrodynamic pressures and forces at masonry bridges. This paper outlines the design of the experimental setup and the reasoning behind the choices for preliminary experimental parameters. The experiments are to include testing of bridge models and various 3D-printed debris shapes under realistic flow conditions. Geometry of the bridge and debris models are kept approximately similar to prototype conditions, with hydraulic conditions of the experiments designed to the degree that experimental constraints allow based on Froude similarity. Velocities, scour and hydrodynamic pressures are measured using an Acoustic Doppler Velocimeter, echo-sounding concept and pressure sensors, respectively. Preliminary results indicate that the designed experiments have the potential to enhance our understanding of the hydrodynamic effects of debris blockage.
\end{abstract}

\section{INTRODUCTION}

\subsection{General}

Bridges built over rivers are often vulnerable to the erosion of soil around their foundations by the action of water flow. This erosion, which is called scour by engineers, can endanger stability of the foundations and consequently that of the bridge structure. While many factors can contribute to the failure of a bridge, scour is widely recognized as the leading cause (e.g. Chang 1973, HR Wallingford 1991, Richardson et al. 1993, Parola et al. 1996, Melville and Coleman 2000, May et al. 2002, Hunt 2009, Ettema et al. 2010, Highways Agency 2012, Benn 2013, Toth 2015). This has been the case in several well-known bridge failures, e.g. Bridge RDG1 48 in 2009 near Feltham in England (Fig. 1), Malahide Viaduct in Ireland in 2009, CPR Bonnybrook Bridge in 2013 in Calgary in Canada, I-10 Bridge in California, US in 2015, and several recent bridge failures in December 2015 in the Cumbria flood in the UK. These failures not only cause economic losses due to the cost of bridge replacement and remedial works, but also disruption to transportation, frustration in users, and even injury or loss of life (Evans et al. 2004, McKibbins et al. 2006).

Debris increases effective width of a pier, and constricts flow, thereby reducing conveyance and increasing water levels at the pier/bridge. Role of debris in enhancing hydraulic loading and scour at culverts and bridge piers and abutments, and increasing risk of failure has been known for a long time (e.g. Laursen \& Torch 1956, Chang \& Shen 1979, Diehl 1997, Parola et al. 2000, May et al. 2002, Bradley et al. 2005, McKibbins et al. 2006, Lagasse et al. 2010, Wallerstein et al. 2010, Arneson et al. 2012, Benn 2013).

Masonry arch bridges form $40 \%$ of the UK bridge stock (Bridle \& Sim 2009). They are cultural and engineering heritages, and also reliable and essential components of transport infrastructure in the UK and other countries (McKibbins et al. 2006). They were typically designed to withstand flood events less severe and less frequent than those happening today (RSSB 2005). Additionally, their special structure, which typically includes short span and low clearance, exposes them to debris blockage which exacerbate scour. Consequently, in the past ten years, these structures have become increasingly vulnera- 
ble to flooding and its induced scour (Kirby et al. 2015).

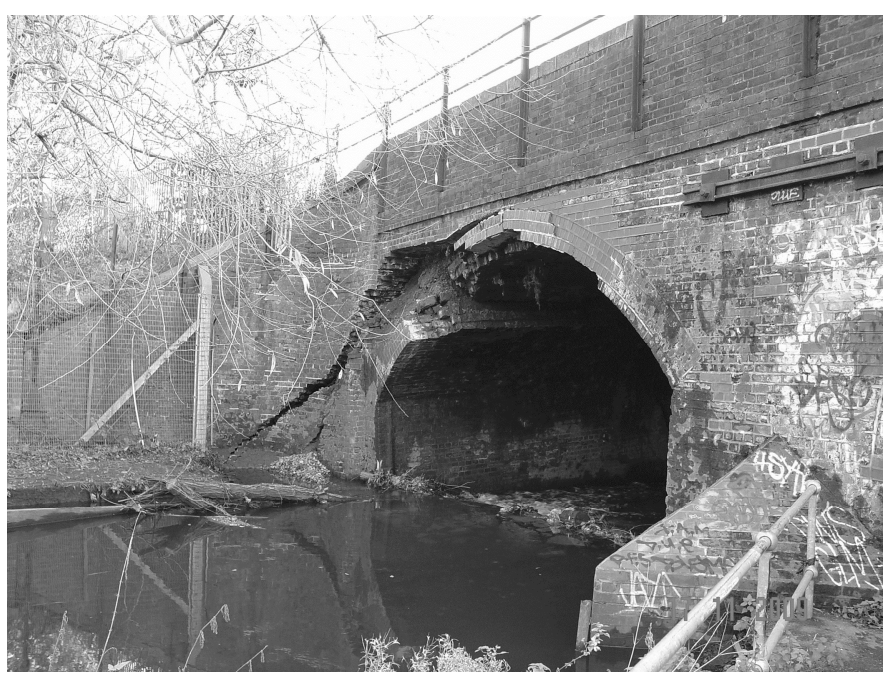

Figure 1. Upstream face of Bridge RDG1 48 showing failed arch following debris blockage (after RAIB 2010).

In spite of recognizing the contributing role of debris in increasing risk of failure, the current UK guidance for assessment of hydraulic action (May et al. 2002, Highway Agency 2012) is highly inadequate for evaluating these risks (House of Commons 2010). Presently the commonly adopted approach to predict scour under debris blockage is increasing pier width based on the original "effective pier width" concept of Melville \& Dongol (1992). However, this approach while still recommended in the recent edition of the UK manual for evaluating scour at bridges (Kirby et al. 2015) needs to be updated as it overestimates effective pier width (Lagasse et al. 2010).

Previous research on pier scour under debris is limited to single pier geometries or pier arrangements, which are not representative of masonry bridges. Also, available investigations have mainly focused on single pier and not the whole bridge. This is particularly important considering the significant number of failures of single span structures on small watercourses due to abutment scour (Benn 2013).

Finally, to the best knowledge of authors, hydrodynamic pressure and forces exerted on the structure due to debris blockage, have never been investigated before. Therefore, there is a pressing need for scientific research to fill the knowledge gaps with respect to the hydrodynamic effects of debris blockage.

Accordingly, a project was defined to investigate effect of debris blockage on flow pattern, scour, and hydrodynamic pressure and forces at masonry bridges under flood conditions. This project has three phases: 1) Laboratory modelling, 2) CFD modelling, and 3) Assessment guidance development. Project outcomes will be built into the existing UK guidance (Kirby et al. 2015) for assessment of bridges under hydraulic action, and is expected to enable improved management of bridges at risk to debris blockage. The present paper reports on preliminary results from the first phase of the project, i.e. flume experiments.

\subsection{Focus of the flume experiments}

The goal of the flume experiments is to test various combinations of debris and structure configurations to provide

1 data for validation purposes of the second phase of the project, i.e. CFD modelling

2 insights for improving available guidelines and maintenance practices.

Single bridge piers, and single and double span arches, with dimensions similar to those of real masonry arches, will be tested to investigate effect of debris blockage on scour.

The process of formation and accumulation of debris will not be investigated in the current project. The focus is only on the effect of accumulated debris on hydrodynamics and scour around piers/bridges.

\section{EXPERIMENTAL SETUP}

The experiments will be carried out in a recirculating flume $0.6 \mathrm{~m}$-wide, $0.65 \mathrm{~m}$-deep and with a $10 \mathrm{~m}$ long working section (Fig. 2). The flume is equipped with a centrifugal pump capable of recirculating solid particles upto $3 \mathrm{~mm}$. The flow rate is measured using an electromagnetic flowmeter located in the suction pipe of the pump (resolution $\pm 0.1 \mathrm{l} / \mathrm{s}$ ). A flow straightening honeycomb and an adjustable weir are installed at the inlet and outlet of the flume, respectively. A mobile digital point gauge (accuracy $0.05 \mathrm{~mm}$ ), will be also used to measure flow depth and ensure uniform flow conditions. A motorized 3axis traverse system on top of the flume will be used

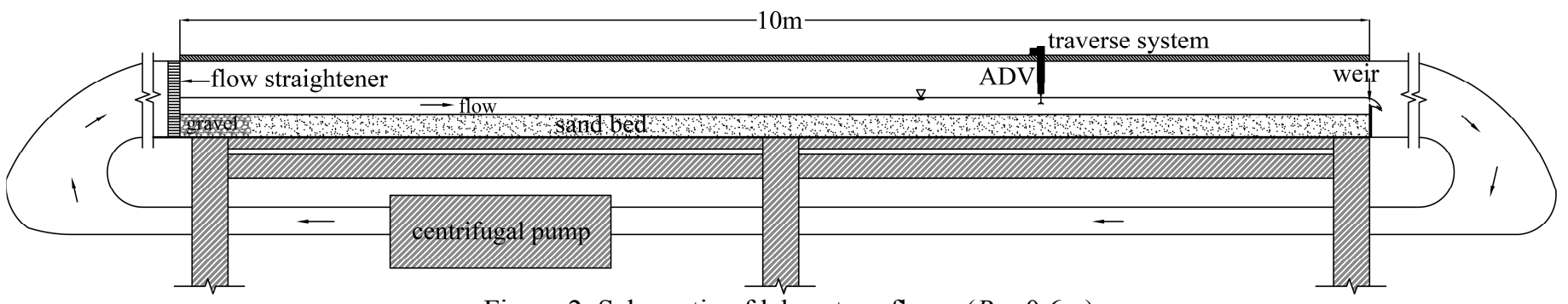

Figure 2. Schematic of laboratory flume $(B=0.6 \mathrm{~m})$ 
to position an ADV probe at predefined $(x, y, z)$ coordinates, with $x, y$ and $z$ being streamwise, cross stream and vertical directions.

Although, strict similitude between flume experiments and prototype is not sought, as far as scaling constraints allow, experiments will be designed according to geometric Froude similarity. Due to the flume width $(=0.6 \mathrm{~m})$, it was decided to use $10: 1$ scale models of short span masonry bridges $(<6 \mathrm{~m}$ spans) for the preliminary stage of the experiments (for double span arch bridges, this ratio needs to be increased). Nevertheless, several challenges exist in scaling prototype conditions to laboratory.

1 Lateral extent of scour can be restricted due to the flume small width.

2 Flume width restricts use of wide piers or bridge models. Frostick et al. (2011) recommend keeping the cross-sectional area of the structure less than $1 / 6$ of that of the flume. This implies the total width (in $y$ direction) of the modelled structure in the present flume must be smaller than $10 \mathrm{~cm}$.

3 In order to reduce side wall effects, flow widthto-depth ratio, $B / h$, should be restricted to $3 \sim 5$ (Whitehouse \& Chesher 1994, Frostick et al. 2011). This restricts the flow depth to $12 \mathrm{~cm}$, which may not be sufficient for modelling high flow stages in flood conditions.

4 Geometric scaling of sediment size from prototype to present flume experiments could necessitate use of very fine particles which can have different behaviour than that of prototype. Otherwise, scale effects cause scour depths which are exaggeratedly high when scaled to prototype conditions (e.g. Ettema et al. 1998).

Authors acknowledge above scaling limitations and their effect on overestimation of scour depth in flume experiments (e.g. Landers \& Mueller 1996, Ettema et al. 1998, Sturm et al. 2004, Lagasse et al. 2010, Fenocchi \& Natalie 2015). However, these will not have a major effect on reliability of the overall project outcomes since flume experiments are aimed mainly at providing data for validation purposes in CFD phase of the project. The CFD models, after initial validation with results from the flume, will be scaled up to represent full-scale con- ditions.

\subsection{Hydraulic conditions}

In addition to pier geometry, flow characteristics and sediment size are of great importance in affecting scour around a bridge pier (e.g. Ettema et al. 2011, van Leeuwen \& Lamb 2014). Accordingly, flow hydraulics are defined so as to have the greatest number of scenarios possible.

\subsubsection{Specification of tests}

Specification of preliminary tests reported in this paper is summarized in Table 1. Tests 1-4 and Tests 4-7 will be carried out with a single pier and a single span arch, respectively. Here, $B=$ flow width, $d_{50}=$ average grain diameter of sediment, $h=$ flow depth, $Q=$ flow rate, $\mathrm{R}=$ flow Reynolds number $(=V h / v$, with $V=Q /(B h)$ being the mean flow velocity, and $v$ as fluid kinematic viscosity, respectively), $\mathrm{F}=$ Froude number $\left(=V /(g h)^{1 / 2}\right.$, where $g$ stands for acceleration due to gravity), $\mathrm{R}^{\star}=$ roughness Reynolds number $\left(=v * k_{S} / v\right.$, with $v^{*}=\left(g S R_{h}\right)^{1 / 2}$ as shear velocity, where $S$ and $R_{h}$ stand for longitudinal slope of the bed and hydraulic radius, respectively, and $k_{s}=2 d_{50}$ as granular roughness, where $d_{50}$ stands for median grain size of sediment), and $V_{c r}=$ critical mean flow velocity for initiation of sediment motion $\left(V / V_{c r}=\right.$ $\eta *^{1 / 2}$, where $\eta *$ is flow intensity calculated according to Yalin $\&$ da Silva 2001). $L_{D}$ and $D_{D}$ are characteristic lengths in each debris configuration as defined in Subsection 2.4.

Reynolds number scaling is relaxed while keeping the flow turbulent $(R>2000-3000$, Chanson 2004). In addition, instead of having strict Froude similitude between model and prototype, flow is generally kept subcritical $(F<1)$. In all tests, the flow is uniform, and in fully rough regime of turbulent flow $\left(R^{*}>70\right.$, Yalin 1992, Yalin \& da Silva 2001). Experiments are carried out in clear-water scour conditions, with $V / V_{c r}$ being just below 1 in order to maximize scour depth.

\subsubsection{Sediment}

Sediment in the current experiments is uniform silica sand. Average grain diameter, $d_{50}$, is identified based on

Table 1. Hydraulic conditions of experiments at present paper $\left(B=60 \mathrm{~cm}, d_{50}=1.37 \mathrm{~mm}\right)$.

\begin{tabular}{|c|c|c|c|c|c|c|c|c|c|}
\hline \multirow[t]{2}{*}{ Test } & $h$ & $Q$ & $\mathrm{R}$ & $F$ & $\mathrm{R}^{*}$ & $V / V_{c r}$ & Debris shape & $L_{D}$ & $D_{D}$ \\
\hline & $\mathrm{cm}$ & $1 / \mathrm{s}$ & - & - & - & - & - & $\mathrm{cm}$ & $\mathrm{cm}$ \\
\hline $1^{*}$ & 7.8 & 19.3 & $32 \times 10^{3}$ & 0.47 & 81 & 0.99 & No debris & - & - \\
\hline $2 *$ & 7.8 & 19.3 & $32 \times 10^{3}$ & 0.47 & 81 & 0.99 & Cylinder & 30 & 1.6 \\
\hline $3 *$ & 7.8 & 19.3 & $32 \times 10^{3}$ & 0.47 & 81 & 0.99 & Cylinder & 30 & 1.6 \\
\hline $4 *$ & 13.5 & 35.9 & $60 \times 10^{3}$ & 0.39 & 82 & 0.99 & Cylinder & 30 & 3.2 \\
\hline 5 & 7.8 & 19.3 & $32 \times 10^{3}$ & 0.47 & 81 & 0.99 & No debris & - & - \\
\hline 6 & 7.8 & 19.3 & $32 \times 10^{3}$ & 0.47 & 81 & 0.99 & Cylinder & 54 & 3.2 \\
\hline 7 & 13.5 & 35.9 & $60 \times 10^{3}$ & 0.39 & 82 & 0.99 & Cylinder & 54 & 3.2 \\
\hline
\end{tabular}

* Scenarios with single pier - Rest are with a single span arch. 
1 flow being in rough turbulent regime $\left(R^{*}>70\right)$

2 avoiding ripple forming sand (i.e. $d_{50}<0$ 0.6$0.7 \mathrm{~mm}$, Raudkivi \& Ettema 1983, Ettema et al. 1998)

3 availability of the grain size on the market.

Accordingly, sands with $d_{50}=1.37 \mathrm{~mm}$ is chosen for present experiments. The scaling ratio 10:1 chosen for the experiments means a grain size of 13.7 $\mathrm{mm}$ in prototype conditions which is realistic (e.g. $d_{50}=10$ and $20 \mathrm{~mm}$ for River Taw and River Yeo in south west England, respectively (private communication); and $d_{50}=21-37 \mathrm{~mm}$ for a $4^{\text {th }}$ order tributary of Lymington River in UK, Dixon 2016).

To evaluate the thickness of sediment bed required in the flume, the anticipated scour depth is estimated using Sheppard/Melville (S/M) equation (Sheppard et al. 2014) for rectangular piers noting that the equation is for estimating scour in the $a b-$ sence of debris. In order to account for the effect of debris, actual pier width was converted conservatively to an effective width using the concept introduced by Melville \& Dongol (1992). Subsequently, a compacted sand bed with sufficient thickness is installed in the flume based on the scour estimate.

\subsection{Experiment duration}

Flume experiments are aimed at quantifying effect of debris blockage on scour. This will be achieved by running experiments with and without debris blockage for equal durations, rather than running for reaching equilibrium scour depth $\left(d_{s e}\right)$. In order to maximize the number of experiments, the duration of one experiment will be less than the time, $t_{e}$, required to achieve equilibrium stage of scour, but enough to achieve about $80 \%$ of equilibrium scour. According to Melville \& Chiew (1999), the time required to reach $80 \%$ of equilibrium scour depth is $0.03 t_{e}$ for a circular pier and when $V / V_{c r}=1$. They however noted that in small scale experiments, experiments may have to be run for several days to reach higher than $50 \%$ of equilibrium depth. This will be investigated in the present experiments for rectangular pier shapes and $V / V_{c r}$ just below 1 .

\subsection{Pier \& bridge models}

In the current project scour will be studied not only around bridge piers, but also at single and double span bridges. Figures 3 and 4 show schematics of a single pier in the middle of the flow, and a single span arch bridge in the flume, respectively.

Scour around a single pier is mostly affected by pier width. Additionally, pier width is recommended to be less than $1 / 6$ of the flume cross section to minimize adverse effect of side walls (Frostick et al. 2011). Accordingly, width of the single pier shown in Figure 3 is set to $50 \mathrm{~mm}$. Pier streamwise length is $156 \mathrm{~mm}$ resulting in a width-to-length ratio of 0.32 , which is the average aspect ratio estimated for several masonry bridge piers mainly in Devon, UK (private communication). Also, triangular cutwaters with base angles $45^{\circ}$ were included at the two noses of the pier as a common feature of masonry piers. Figure 3 also shows schematics of a cylindrical debris element, an Acoustic Doppler Velocimeter (ADV) probe for measuring velocities, and a point gauge for measuring flow free surface.

The single span arch shown in Figure 4 is a scale model of Canns Mill Bridge in Devon, UK. The abutment widths are however reduced to minimize the ratio of structure width to that of flow. Streamwise length is identified with $340 \mathrm{~mm}$, resulting in the span length $(466 \mathrm{~mm})$ to streamwise length being 0.73 which is the estimated average for several masonry bridges mainly in Devon, UK. Figure 4 also shows schematic pressure taps used for measuring hydrodynamic pressure (see Subsection 3.3).

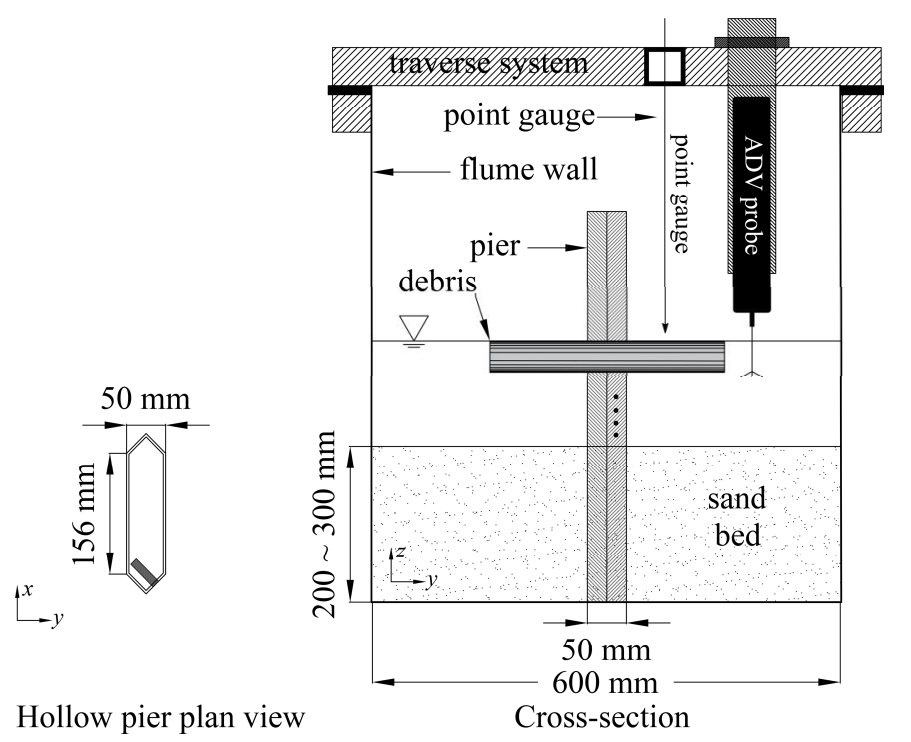

Figure 3. Plan (left) and cross-sectional (right) schematics of a sample pier in the middle of the flow (pressure transducers embedded in the hollow pier are shown by hatch pattern in plan view with the pressure measurement taps shown by dots in cross-section).

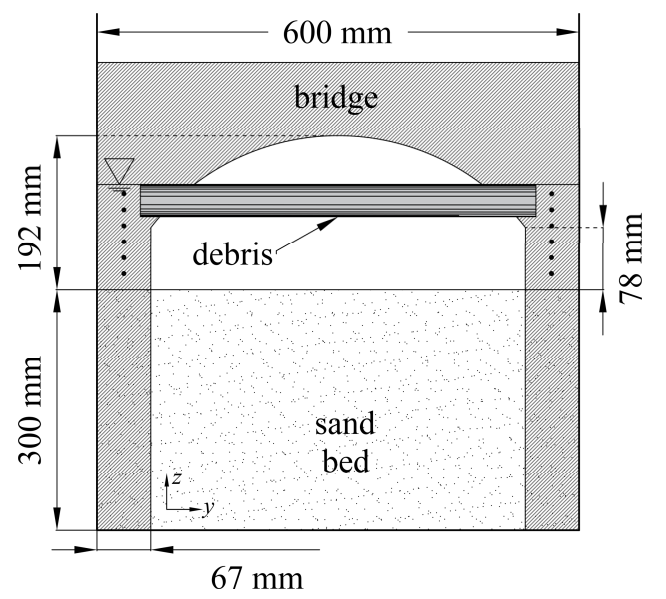

Figure 4. Cross-sectional schematic of a single span arch. Streamwise length is $340 \mathrm{~mm}$. Pressure measurement taps shown by dots on the abutments. 


\subsection{Debris models}

Woody debris is the most common form of debris in watercourses (e.g. Harmon et al. 1986, Gippel 1999). Woody debris can include tree trunks and logs travelling individually (Chang \& Shen 1979), or a jam of logs and/or tree branches and twigs and leaves (e.g. Bradley 2005, Lagasse et al. 2010, Weeks et al. 2013). Due to the variability of debris shapes, dimensions and types from one stream to another, in the present paper, debris is not scaled down from any particular geographical location, but effect of a certain debris configuration is investigated on scour.

\subsubsection{Shape}

In the current project, woody debris is grouped into two general categories of individual debris and debris jam, with the focus of the present paper being on individual debris.

Individual woody debris can range from small (e.g. leaves and sticks) to large (logs and trees) floating debris (e.g. Bradley et al. 2005). Individual debris with significant effect on flow and scour at bridges are tree trunks (Lagasse et al. 2010, Dixon 2016), where often rootwad is still attached to them.

Individual debris in the present paper are represented by simple cylindrical elements. Effect of rootwads will be investigated in the next stages of the project.

\subsubsection{Dimensions}

Although strict scaling is not sought in the current project, diameter and length of the cylindrical elements used as debris are chosen so as to be similar to prototype tree logs. Average log diameter to length, $D_{D} / L_{D}$, is the main criterion for characterizing tree logs, and is specified as 0.059 , which is the average value from several field studies in US, Germany and Italy (Beechie \& Sibley 1997, Diehl 1997, Kail 2003, Comiti et al. 2006, Magilligan et al. 2008).

Debris configurations in case of a single pier are summarized in the four first rows of Table 1. Test 1 will be carried out without debris as a reference, with debris length and diameter in Tests $2 \& 3$ being identified with $L_{D}=30 \mathrm{~cm}$ covering half of the flow width and $D_{D}=1.6 \mathrm{~cm}\left(D_{D} / L_{D}=0.053\right)$, respectively. An additional scenario with $L_{D}=30 \mathrm{~cm}$ and $D_{D}=$ $3.2 \mathrm{~cm}$ will be run for preliminary investigation of effect of cylindrical debris diameter on scour.

Debris configurations in single span arch experiments, i.e. Tests 5-7, are also summarized in Table 1. Debris length and diameter are specified as $L_{D}=$ $54 \mathrm{~cm}$ to cover the whole bridge span and $D_{D}=3.2$ $\mathrm{cm}\left(D_{D} / L_{D} \approx 0.059\right)$, respectively.

\subsubsection{Elevation in water column}

From Laursen \& Torch (1956), Diehl (1997) and Lagasse et al. (2010), it is apparent that debris can be buried in the bed, transported at flow surface, or submerged. While debris jam can grow from water surface toward the bed, individual tree logs and trunks are expected to be transported at the water surface (Diehl 1997, Lagasse et al. 2010, Weeks et al. 2013).

In the present paper and similar to several other authors (e.g. Melville \& Dongol 1992, Wallerstein et al. 2001, Lagasse et al. 2010, Schmocker \& Hager 2011, Pagliara \& Carnacina 2013), individual cylindrical debris will be positioned just below the flow free surface. This will be achieved by fixing debris to the pier/bridge model at the appropriate elevation relative to the flow depth.

\subsubsection{Material and fabrication}

Debris in several flume studies, including those studying debris effect either on channel morphology or pier/bridge, has been simulated using wooden elements or natural twigs (e.g. Laursen \& Toch 1956, Cherry \& Beschta, 1989; Braudrick \& Grant 2001; Wallerstein et al., 2001, Lyn et al. 2003, Lagasse et al. 2010, Pagliara \& Carnacina 2010 and 2013, Schmocker \& Hager 2011) and also synthetic material (e.g. Parola et al. 2000, Lagasse et al. 2010, Pagliara \& Carnacina 2011).

In the present study, debris elements will be fabricated via $3 \mathrm{D}$ printing using nylon powder. This is thought to be a useful technique to fabricate more complicated debris shapes in the next stages of the project. Debris element produced via this technique are solid and have density enough to float on flow free surface. However, since debris elements will be fixed to the pier/bridge at a certain elevation, density is expected not to be relevant.

\section{PLANNED MEASUREMENTS}

The experimental design, described in Section 2 of the paper, has now been set up in the Fluids Laboratory at the University of Exeter. The planned experiments are currently underway and preliminary results shall be presented at the conference.

\subsection{Velocity}

Velocity measurements in the current project will be carried out with the aid of a Vectrino Profiler ADV (accuracy $0.5 \%$ of measured velocity), installed on the 3-axis traverse system and shown schematically in Figures 2 \& 3.

In scour experiments, due to the bed continuously being eroded, it is not possible to keep the hydraulic conditions constant and do velocity measurements at different positions using ADV. Therefore, in the current project, velocity measurements will be mainly carried out at a single position corresponding to the maximum scour, with several other measurements 
being done at other points as far as experimental constraints allow.

\subsection{Scour}

During each experiment, scour evolution will be monitored at the location of expected maximum scour (upstream nose for a single blunt pier, e.g. Breusers et al. 1977, Lagasse et al. 2010) via the distance measurement feature of ADV probe working based on echo sounding concept (accuracy of 0.5 $\mathrm{mm}$ and sampling rate upto $10 \mathrm{~Hz}$ ).

Additionally scour hole geometry will be surveyed at a few time steps of each experiment by stopping the experiment with caution so as not to disturb the scour geometry, and surveying the bed around pier/bridge model on a mesh of predefined $(x, y)$ points, subsequently.

\subsection{Hydrodynamic pressure}

In the current project, hydrodynamic pressure will be measured at several points on the pier/bridge models to study the effect of debris on pressure distribution at the structure. Hydrodynamic pressures are expected to be less than 100 mbar and will be measured using either 1. pressure transducers (accuracy of 0.05 mbar) or 2. pitot tubes mounted at pressure taps and a digital manometer (see Figures $3 \&$ 4).

\section{FUTURE RESEARCH}

\subsection{Flume experiments}

Future experimental research will investigate debris effects on scour from the following standpoints:

- Debris dimensions

- Abutment width

- Sand grain size

- Short-duration high flow (flood peak) with constant discharge in live-bed conditions

- Complete flood (unsteady flow) simulation.

Each of above aspects will be investigated in single pier, single span arch, and double span arch as time constraints allow.

\subsection{CFD modelling}

To predict sediment erosion and flow behaviour in case of blockage of bridges by debris, CFD will be employed. This complex system of sediment transport and fluid flow requires multiphase and turbulence modelling. The volume of fluid (VOF) method is chosen to describe the free surface flow due to its capability for accurately treating complicated free boundary configurations. In terms of turbulence modelling Reynolds averaged Navier-
Stokes (RANS) equations will be implemented. Simulation results will be validated with the experimental data and model performance will be optimised. In this work, we attempt to overcome the limitations of the experimental set up and scale by tightly coupling numerical and experimental modelling.

\section{CONCLUDING REMARKS}

Due to the vitality of masonry bridges in the UK infrastructure network and their vulnerability to flooding, a research project is defined to investigate the effects of debris blockage on flow patterns, scour, and hydrodynamic pressures at masonry bridges under flood conditions. This project has the following three phases: laboratory experimentation, CFD modelling, and development of assessment guidance. This paper explains the design of the flume experiments for the first phase, while outlining the various challenges in the process. Preliminary results from experiments shall be presented at the conference.

\section{ACKNOWLEDGEMENT}

The research presented in this paper was supported by funding from the UK's Engineering and Physical Sciences Research Council (EPSRC) under grant EP/M017354/1. The authors are grateful to project partners for their support, particularly Devon County Council and Network Rail for providing useful prototype data.

\section{REFERENCES}

Arneson, L.A., Zevenbergen, L.W., Lagasse, P.F. \& Clopper, P.E. 2012. Evaluating scour at bridges (No. FHWA-HIF12-003).

Benn, J. 2013. Railway Bridge Failure during Flood in the UK and Ireland: Learning from the Past. Proceedings of the Fifth International Conference on Forensic Engineering, ICE Publishing, UK.

Bradley, J.B., Richards, D.L. \& Bahner, C.C. 2005. Debris control structures: Evaluation and countermeasures. US Department of Transportation, Federal Highway Administration.

Braudrick, C.A. \& Grant, G.E. 2001. Transport and deposition of large woody debris in streams: a flume experiment. $\mathrm{Ge}$ omorphology, 41(4), pp.263-283.

Breusers, H.N.C., Nicollet, G. \& Shen, H.W. 1977. Local scour around cylindrical piers. Journal of Hydraulic Research, 15(3), pp.211-252.

Bridle, R.J. \& Sims, F. 2009. The effect of bridge failures on UK technical policy and practice. Proceedings of the Institution of Civil Engineers - Engineering History and Heritage 162(1): 39-49.

Chang, F.F. 1973. A statistical summary of the cause and cost of bridge failures (No. FHWA-RD-75-87 Final Report).

Chang, F.F. \& Shen, H.W. 1979. Debris problems in the river environment (No. FHWA-RD-79-62 Final Report). 
Chanson, H. 2004. The hydraulics of open channel flow: An introduction. Butterworth-Heinemann.

Cherry, J. \& Beschta, R.L., 1989. Coarse woody debris and channel morphology: A flume study. JAWRA Journal of the American Water Resources Association, 25: 1031-1036.

Comiti, F., Andreoli, A., Lenzi, M.A. \& Mao, L. 2006. Spatial density and characteristics of woody debris in five mountain rivers of the Dolomites (Italian Alps). Geomorphology, 78(1), pp.44-63.

Diehl, T.H. 1997. Potential drift accumulation at bridges. US Department of Transportation, Federal Highway Administration, Research and Development, Turner-Fairbank Highway Research Center.

Dixon, S.J. 2016. A dimensionless statistical analysis of logjam form and process. Ecohydrology.

Ettema, R., Melville, B.W. \& Barkdoll, B. 1998. Scale effect in pier-scour experiments. Journal of Hydraulic Engineering, 124(6), pp.639-642.

Ettema, R., Melville, B.W. \& Constantinescu, G. 2011. Evaluation of bridge scour research: Pier scour processes and predictions. Washington, DC: Transportation Research Board of the National Academies.

Ettema, R., Nakato, T. \& Muste, M., 2010. Estimation of scour depth at bridge abutments. Final Rep. for NCHRP Project 24-20. National Cooperative Highway Research Program.

Evans, E.P., Ashley, R., Hall, J., Penning-Rowsell, E., Saul, A., Sayers, P., Thorne, C. R. \& Watkinson, A. 2004. Foresight. Future Flooding. Scientific Summary: Volume 1 - Future Risks and their Drivers, DTI/pub 7183/2k/04/04/NP, URN 04/939.

Fenocchi, A. \& Natale, L. 2015. Using Numerical and Physical Modeling to Evaluate Total Scour at Bridge Piers. Journal of Hydraulic Engineering, p.06015021.

Frostick, L.E., McLelland, S.J. \& Mercer, T.G. (2011). Users guide to physical modelling and experimentation: Experience of the HYDRALAB network. CRC Press.

Gippel, C.J. 1995. Environmental hydraulics of large woody debris in streams and rivers. Journal of Environmental Engineering, 121(5), pp.388-395.

Harmon, M.E., Franklin, J.F., Swanson, F.J., Sollins, P., Gregory, S.V., Lattin, J.D., Anderson, N.H., Cline, S.P., Aumen, N.G., Sedell, J.R. \& Lienkaemper, G.W. 1986. Ecology of coarse woody debris in temperate ecosystems. Advances in ecological research, 15(133), p.302.

Highways Agency. 2012. The assessment of scour and other hydraulic actions at highway structures. In Highways Agency, Design manual for roads and bridges, vol 3, section 4, Part 21, BD 97/12. London.

House of Commons. 2010. The impact of flooding on bridges and other transport infrastructure in Cumbria. London.

HR Wallingford \& T. P. O'Sullivan \& Partners. 1991. Hydraulics of highway structures. Report EX2404 Part 1. Contract report for Transport and Road Research Laboratory.

Hunt, B.E. 2009. Monitoring scour critical bridges (Vol. 396). Transportation Research Board.

Kail, J. 2003. Influence of large woody debris on the morphology of six central European streams. Geomorphology, 51(1), pp.207-223.

Kirby, A.M, Roca, M., Kitchen, A., Escarameia, M. \& Chesterton, O.J. 2015. Manual on scour at bridges and other hydraulic structures, second edition (Vol. C742). London: CIRIA.

Lagasse, P.F., Clopper, P.E., Zevenbergen, L.W., Spitz, W.J. \& Girard, L.G. 2010. Effects of debris on bridge pier scour (Vol. 653). Transportation Research Board.

Landers, M. \& Mueller, D. 1996. Evaluation of selected pierscour equations using field data. Transportation Research Record: Journal of the Transportation Research Board, (1523), pp.186-195.
Laursen, E.M. \& Toch, A. 1956. Scour around bridge piers and abutments (Vol. 4). Iowa Highway Research Board.

Lyn, D., Cooper, T., Yi, Y., Sinha, R. \& Rao, A. 2003. Debris accumulation at bridge crossings: laboratory and field studies. Joint Transportation Research Program, p.48.

Magilligan, F.J., Nislow, K.H., Fisher, G.B., Wright, J., Mackey, G. \& Laser, M. (2008). The geomorphic function and characteristics of large woody debris in low gradient rivers, coastal Maine, USA. Geomorphology, 97(3), pp.467-482.

May, R.W.P., Ackers, J.C. \& Kirby, A.M. 2002. Manual on scour at bridges and other hydraulic structures (Vol. 551). London: CIRIA.

McKibbins, L.D., Melbourne, C., Sawar, N. \& Gaillard, S.C. 2006. Masonry arch bridges: condition appraisal and remedial treatment (Vol. C656). London: CIRIA.

Melville, B.W. \& Chiew, Y.M. 1999. Time scale for local scour at bridge piers. Journal of Hydraulic Engineering, 125(1), pp.59-65.

Melville, B.W. \& Coleman, S.E. 2000. Bridge scour. Water Resources Publication.

Melville, B.W. \& Dongol, D.M., 1992. Bridge pier scour with debris accumulation. Journal of Hydraulic Engineering, 118(9), pp.1306-1310.

Pagliara, S. \& Carnacina, I., 2010. Temporal scour evolution at bridge piers: Effect of wood debris roughness and porosity. Journal of Hydraulic Research, 48(1), pp.3-13.

Pagliara, S. \& Carnacina, I., 2011. Influence of large woody debris on sediment scour at bridge piers. International Journal of Sediment Research, 26(2), pp.121-136.

Pagliara, S. \& Carnacina, I. 2013. Bridge pier flow field in the presence of debris accumulation. Proceedings of the Institution of Civil Engineers-Water Management (Vol. 166, No. 4, pp. 187-198).

Parola, A.C. Apeldt, C.J. \& Jempson, M.A. 2000. Debris forces on highway bridges (No. 445). Transportation Research Board.

Parola, A.C., Hagerty, D.J., Mueller, D.S., Melville, B.W., Parker, G. \& Usher, J.S. 1996. The need for research on scour at bridge crossings. In Managing Water@sCoping with Scarcity and Abundance (pp. 124-129). ASCE.

RAIB 2010. Failure of Bridge RDG1 48 (River Crane) between Whitton and Feltham 14 November 2009. Derby, UK.

Raudkivi, A.J. \& Ettema, R. 1983. Clear-water scour at cylindrical piers. Journal of Hydraulic Engineering, 109(3), pp.338-350.

Richardson, E.V., Harrison, L.J., Richardson, J.R. \& Davis, S.R. 1993. Evaluating scour at bridges. No. HEC $18\left(2^{\text {nd }}\right.$ ed).

RSSB 2005. Safe Management of Railway Structures, Phase 1: Flooding \& Scour Risk. London.

Schmocker, L. \& Hager, W.H. 2011. Probability of drift blockage at bridge decks. Journal of Hydraulic Engineering, 137(4), pp.470-479.

Sheppard, D., Melville, B. \& Demir, H. 2014. Evaluation of Existing Equations for Local Scour at Bridge Piers. Journal of Hydraulic Engineering, 140(1), pp.14-23

Sturm, T., Sotiropoulos, F., Landers, M., Gotvald, T., Lee, S., Ge, L., Navarro, R. \& Escauriaza, C. 2004. Laboratory and $3 D$ Numerical Modeling with Field Monitoring Or Regional Bridge Scour in Georgia. Georgia Department of Transportation, Office of Materials Research, Research and Development Branch.

Toth, E. 2015. Asymmetric Error Functions for Reducing the Underestimation of Local Scour around Bridge Piers: Application to Neural Networks Models. Journal of Hydraulic Engineering, 141(7), p.04015011. 
van Leeuwen, Z. \& Lamb, R. 2014. Flood and scour related failure incidents at railway assets between 1846 and 2013. Project W13-4224. JBA Trust Limited.

Wallerstein, N.P., Alonso, C.V., Bennett, S.J. \& Thorne, C.R. 2001. Distorted Froude-scaled flume analysis of large woody debris. Earth Surface Processes and Landforms, 26(12), pp.1265-1283.

Wallerstein, N.P., Arthur, S. \& Sisinngghi, D. 2010. Towards predicting flood risk associated with debris at structures. Proceedings of the IAHR APD conference 2010.

Weeks, W., Witheridge, G., Rigby, E. \& Barthelmess, A. 2013. Project 11: blockage of hydraulic structures. Engineers Australia.

Whitehouse, R.J.S., Chesher, T.J. 1994. Seabed roughness in tidal flows - a review of existing measurements. Report SR360, HR Wallingford.

Yalin, M.S. 1992. River Mechanics, Pergamon Press, Oxford.

Yalin, M.S. \& da Silva, A.M.F. 2001. Fluvial Processes, IAHR Monograph, IAHR, Delft. 